\title{
The Influences of Arctic \& North Atlantic Oscillations on Temperature and Precipitation Data of Eastern and Northern Marmara
}

\section{Arktik \& Kuzey Atlantik Salınımlarının Doğu ve Kuzey Marmara'nın Sıcaklık ve Yağış Verileri Üzerindeki Etkileri}

\author{
Cenk SEZEN, Turgay PARTAL \\ Ondokuz Mayts University, Department of Civil Engineering, Samsun, Turkey \\ cenk.sezen@omu.edu.tr (0000-0003-1088-9360), turgay.partal@omu.edu.tr (0000-0002-3779-441X) \\ Received Date: 24.07.2018, Accepted Date: 24.12.2018
}

\begin{abstract}
Arctic Oscillation and North Atlantic Oscillation are the two types of the teleconnections which have an influence area particularly at Northern Hemisphere (Russia, Canada, China, United States of America, India, Kazakhstan, Algeria, Saudi Arabia, Mexico and Sudan). To reveal the relation between Arctic Oscillation, North Atlantic Oscillation and temperature, precipitation regime of Eastern and Northern parts of Marmara in Turkey, correlation coefficients were calculated. With our study it was obtained that temperature values under the impact of Arctic Oscillation (-), North Atlantic Oscillation (-) were generally higher than the values under the effect of Arctic Oscillation (+), North Atlantic Oscillation (+). However, it was seemed that the relationship between precipitation data and the phases of atmospheric indices were more complicated. As a result, this study proved that the influence of atmospheric teleconnections on the hydro-meteorological parameters is necessary for the effective management and prediction of water resources.

Keywords: Arctic Oscillation, North Atlantic Oscillation, Marmara region, precipitation, temperature

$\ddot{O z}$

Arktik Salınım ve Kuzey Atlantik Salınımı özellikle Kuzey Yarımküre'de (Rusya, Kanada, Amerika Birleşik Devletleri, Hindistan, Kazakistan, Cezayir, Suudi Arabistan, Meksika ve Sudan) etki alanına sahip olan tele bağlantılardan iki tanesidir. Arktik Salınım, Kuzey Atlantik Salınımı ve Türkiye'nin Doğu ve Kuzey Marmara kesiminde sıcaklık, yağış rejimi arasındaki ilişkiyi ortaya koymak için korelasyon katsayıları hesaplanmıştır. Çalışmamızda Arktik Salınım (-), Kuzey Atlantik Salınımı (-) etkisi altındaki sıcaklık değerlerinin Arktik Salınım (+),Kuzey Atlantik Salınımı (+) etkisi altındaki sıcaklık değerlerinden genel olarak daha yüksek olduğu elde edilmiştir. Ancak, yağış verisi ve atmosferik indislerin fazları arasındaki ilişkinin daha karmaşı olduğu görülmektedir. Sonuç olarak, bu çalışma atmosferik indislerin hidrometeorolojik parametreler üzerindeki etkisinin su kaynaklarının yönetimi ve tahmini için gerekli olduğunu ortaya koymuştur.
\end{abstract}

Anahtar kelimeler: Arktik Salınım, Kuzey Atlantik Salınımı, Marmara bölgesi, , yağıș, sıcaklık

\section{Introduction}

The impacts of atmospheric events on hydrological cycle are very significant with regard to water resources management and hydrological cycle. In this regard, the influence of atmospheric teleconnections on hydrometeorological variables such as rainfall, temperature or streamflow which need be taken into consideration for design of water structures like dams or prevention of flood or drought risks, is revealed in many studies (Rodo et al, 1997; Givati and Rosenfeld, 2013). All these studies show that atmospheric teleconnections have different effects on hydrometeorological variables with reference to hydrological cycle. Accordingly, the research on Southern Oscillation (SO) and North Atlantic Oscillation (NAO) that are wellrecognized atmospheric indices have become widespread not only around the world but also in 
Turkey (Kahya and Karabörk, 2001; Brönnimann, 2007; Turkes and Erlat, 2009). In this respect, it is indicated that $\mathrm{SO}$ and $\mathrm{NAO}$ have various impacts on hydrometeorological variables (eg: decreasing of precipitation, temperature rise) in different parts of the world. Rodo et al. (1997) scrutinize the effects of El Niño Southern Oscillation (ENSO) and NAO on the precipitation regime of Southern Europe. They reveal that ENSO and NAO affect the climate characteristics of different regions of Iberian Peninsula. Kadioglu et al. (1999) investigate the linkage between precipitation and E1 Niño events in Turkey and they find out that the precipitation pattern of southern Turkey is associated with ENSO. Cullen et al (2002) investigate the relationship between NAO and streamflow data in Tigris-Europhates, JordanYarmouk and Ceyhan rivers. They state that NAO could be influential on the streamflow regime for the winter-spring (DJFM) period. Turkes and Erlat (2003) analyze the relationship between NAO and precipitation regime throughout Turkey. They emphasize that the amount of precipitation during the negative phase of NAO is higher than the precipitation amount during positive phase of NAO. They also point out that the most remarkable link between the $\mathrm{NAO}$ and Turkey precipitation data are obtained in winter season in comparison with other seasons. Karabork et al. (2005) research the connections between the NAO/SO indices and climate parameters in Turkey. They state that minimum temperature values are associated with ENSO, whereas NAO has influences on either winter precipitation or winter streamflow pattern. They also add that precipitation and streamflow pattern could be associated with the NAO effect according to lag correlation analysis. Karabork and Kahya (2009) investigate the influence of SO and Multivariate ENSO Index (MEI) on temperature, precipitation and streamflow data in Turkey. They find that precipitation and streamflow data have significant correlations with SO and MEI especially in western Turkey. Kucuk et al. (2009) examine whether NAO affects the water levels of lakes in Turkey or not. They ascertain that NAO has a significant relation with the water levels of Lakes Tuz, Sapanca and Uluabat. Chowdhury and Beecham (2010) study upon the rainfall trends in some locations of Australia and they determine that some of the rainfall trends are connected with the SO index. Burt and Howden (2013) analyze the relationship between the NAO and precipitation/streamflow pattern of upland areas in Britain. They indicate that precipitation regime of upland areas has significant positive correlation with the NAO index particularly in autumn, winter and spring seasons. Furthermore, they also state that in case $\mathrm{NAO}(+)$ is influential, flow regime tends to be higher, while even drought conditions occur under the influence of NAO (-). Likewise, impacts of Arctic Oscillation (AO) on climate parameters have been also investigated in recent years (Wang et al., 2005; Tremblay et al., 2011; Wang et al., 2013). Thompson and Wallace (1998) ascertain that although $\mathrm{NAO}$ and $\mathrm{AO}$ indices are similar to each other, $\mathrm{AO}$ is influential on larger part of the Northern Hemisphere as compared with NAO. Turkes and Erlat (2008) investigate the influences of $\mathrm{AO}$ on the winter temperature throughout Turkey, and they find the negative correlations between $\mathrm{AO}$ index and temperature data during the winter season. Givati and Rosenfeld (2013) research the linkage between the AO and precipitation regime of Eastern Mediterranean basin. They determine that when the AO index rises, the winter precipitation decreases in some parts of Eastern Mediterranean basin.

The main objective of this paper is to determine the possible correlation between AO-NAO and temperature, precipitation data of Eastern and Northern Marmara in Turkey. For this purpose, Pearson correlation coefficients are calculated and used to quantify a relationship between atmospheric indices and aforementioned climate variables. Then, results of correlation analysis are assessed via Student t-test at the significance level of $\alpha=0.10, \alpha=0.05$ and $\alpha=0.01$. Furthermore, the temperature and precipitation differences which are based on the negative and positive phases of NAO and $\mathrm{AO}$ are addressed. Consequently, the effects of NAO and AO on the temperature and precipitation regime are determined. 


\section{Study Area}

\section{Method}

The relationship between $\mathrm{AO}, \mathrm{NAO}$ as atmospheric indices and temperature, precipitation data as climate variables were investigated both seasonally and annually in Eastern and Northern Marmara. Temperature and precipitation data in this study were obtained from seven stations of the Turkish State Meteorological Service. Location of the stations used in this study is shown in Figure 1. The stations were selected based on the availability of recorded data for approximately 50 years. The date range for each station is indicated in Table 1.
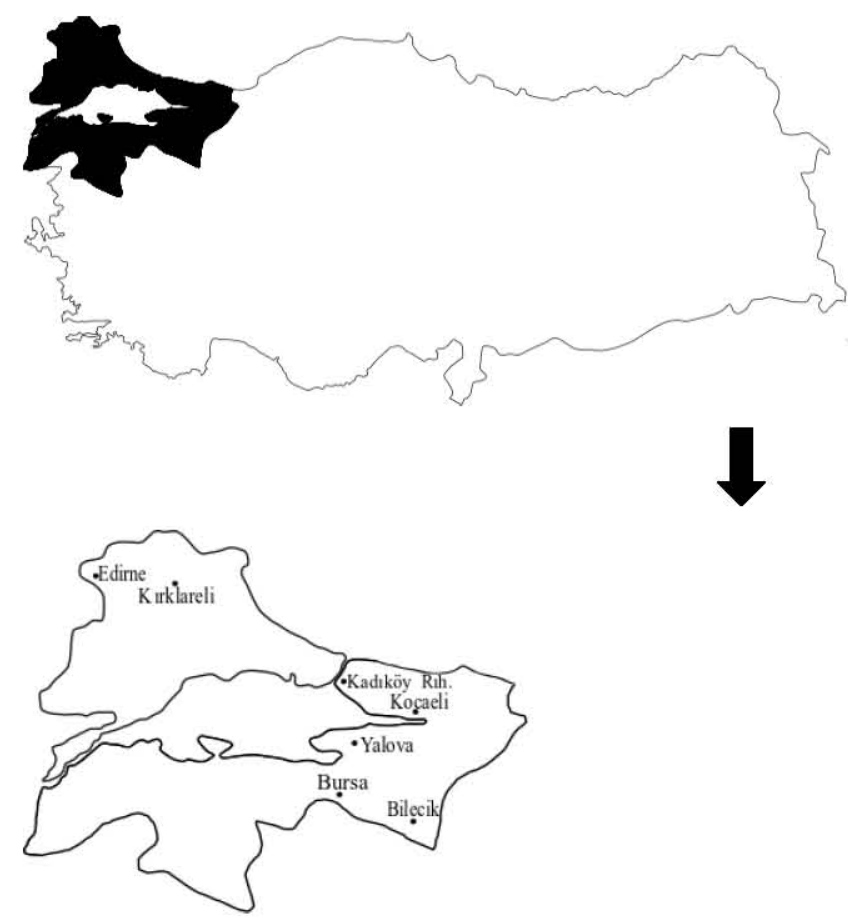

Figure 1. Stations throughout Marmara region.

Table 1

Date Range for Temperature and Precipitation Data

\begin{tabular}{ccc}
\hline & \multicolumn{2}{c}{ Date Range } \\
\cline { 2 - 3 } Location of & Temperature & Precipitation \\
Stations & & $1960-2015$ \\
\hline Edirne & $1960-2015$ & $1963-2015$ \\
Kirklareli & $1963-2015$ & $1960-2015$ \\
Kadiköy Rihtım & $1960-2015$ & $1961-2015$ \\
Kocaeli & $1961-2015$ & $1960-2015$ \\
Yalova & $1960-2015$ & $1960-2015$ \\
Bursa & $1960-2015$ & $1960-2015$ \\
Bilecik & $1960-2015$ & \\
\hline
\end{tabular}

The statistical data concerning the temperature and precipitation for winter (December, January, February), spring (March, April, May), summer (June, July, August) and autumn (September, October, November) seasons were given in Tables 2 and 3. In addition, NAO data was obtained via North Atlantic Oscillation Index (2018) and AO data was acquired by means of Arctic Oscillation Index (2018). 
Table 2

Statistical Data of Mean Temperature for Each Station

\begin{tabular}{cccccccccccc}
\hline & \multicolumn{3}{c}{ Winter } & \multicolumn{2}{c}{ Spring } & \multicolumn{2}{c}{ Summer } & \multicolumn{2}{c}{ Autumn } & \multicolumn{2}{c}{ Annual } \\
\cline { 2 - 12 } Stations & $\begin{array}{c}\text { Mean } \\
\text { Temp. } \\
\left({ }^{\circ} \mathrm{C}\right)\end{array}$ & $\begin{array}{c}\text { Std.Dev. } \\
\left({ }^{\circ} \mathrm{C}\right)\end{array}$ & $\begin{array}{c}\text { Mean } \\
\text { Temp } \\
\left({ }^{\circ} \mathrm{C}\right)\end{array}$ & $\begin{array}{c}\text { Std.Dev } \\
\left({ }^{\circ} \mathrm{C}\right)\end{array}$ & $\begin{array}{c}\text { Mean } \\
\text { Temp. } \\
\left({ }^{\circ} \mathrm{C}\right)\end{array}$ & $\begin{array}{c}\text { Std.Dev. } \\
\left({ }^{\circ} \mathrm{C}\right)\end{array}$ & $\begin{array}{c}\text { Mean } \\
\text { Temp. } \\
\left({ }^{\circ} \mathrm{C}\right)\end{array}$ & $\begin{array}{c}\text { Std.Dev. } \\
\left({ }^{\circ} \mathrm{C}\right)\end{array}$ & $\begin{array}{c}\text { Mean } \\
\text { Temp. } \\
\left({ }^{\circ} \mathrm{C}\right)\end{array}$ & $\begin{array}{c}\text { Std.Dev. } \\
\left({ }^{\circ} \mathrm{C}\right)\end{array}$ \\
\hline Edirne & 3.9 & 1.2 & 13 & 1.1 & 23.9 & 1.1 & 14.4 & 1.0 & 13.8 & 0.7 \\
Kirklareli & 4.0 & 1.2 & 12.1 & 1.1 & 22.9 & 1.0 & 14.0 & 1.0 & 13.3 & 0.7 \\
Kadiköy & 6.8 & 1.1 & 12.3 & 1.2 & 23.1 & 1.1 & 15.9 & 1.0 & 14.6 & 0.8 \\
Rih. & & & & & & & & & & \\
Kocaeli & 7.1 & 1.2 & 13.1 & 1.1 & 23.1 & 0.9 & 16.1 & 1.01 & 14.9 & 0.7 \\
Yalova & 7.3 & 1.1 & 12.6 & 1.1 & 22.9 & 1.0 & 15.9 & 0.9 & 14.7 & 0.7 \\
Bursa & 6.3 & 1.3 & 13.0 & 1.1 & 23.7 & 1.0 & 15.4 & 0.9 & 14.6 & 0.7 \\
Bilecik & 3.6 & 1.5 & 11.5 & 1.1 & 21.4 & 1.0 & 13.8 & 1.1 & 12.6 & 0.8 \\
\hline
\end{tabular}

Note. Std. Dev. $=$ Standard Deviation.

Table 3

Statistical Data of Precipitation for Each Station

\begin{tabular}{|c|c|c|c|c|c|c|c|c|c|c|}
\hline \multirow[b]{2}{*}{ Stations } & \multicolumn{2}{|c|}{ Winter } & \multicolumn{2}{|c|}{ Spring } & \multicolumn{2}{|c|}{ Summer } & \multicolumn{2}{|c|}{ Autumn } & \multicolumn{2}{|c|}{ Annual } \\
\hline & $\begin{array}{l}\text { Mean } \\
\text { Prep. } \\
(\mathrm{mm})\end{array}$ & $\begin{array}{l}\text { Std.Dev. } \\
(\mathrm{mm})\end{array}$ & $\begin{array}{l}\text { Mean } \\
\text { Prep. } \\
(\mathrm{mm})\end{array}$ & $\begin{array}{c}\text { Std.Dev. } \\
(\mathrm{mm})\end{array}$ & $\begin{array}{l}\text { Mean } \\
\text { Prep. } \\
(\mathrm{mm})\end{array}$ & $\begin{array}{l}\text { Std.Dev. } \\
(\mathrm{mm})\end{array}$ & $\begin{array}{l}\text { Mean } \\
\text { Prep. } \\
(\mathrm{mm})\end{array}$ & $\begin{array}{l}\text { Std.Dev. } \\
(\mathrm{mm})\end{array}$ & $\begin{array}{l}\text { Mean } \\
\text { Prep. } \\
(\mathrm{mm})\end{array}$ & $\begin{array}{c}\text { Std.Dev. } \\
(\mathrm{mm})\end{array}$ \\
\hline Edirne & 186.5 & 82.8 & 152.1 & 51.5 & 100.6 & 49.6 & 159.4 & 69.8 & 598.5 & 131.1 \\
\hline Kirklareli & 180.7 & 82 & 141.1 & 48.2 & 94.7 & 48.5 & 153.9 & 65.4 & 570.4 & 134.6 \\
\hline $\begin{array}{c}\text { Kadiköy } \\
\text { Rih. }\end{array}$ & 257.6 & 85.8 & 139.5 & 50.9 & 74.4 & 47.0 & 193.7 & 64.6 & 665.2 & 125.6 \\
\hline Kocaeli & 274.4 & 75.9 & 172.7 & 53.7 & 133.7 & 78.0 & 227.8 & 81.0 & 808.6 & 131.9 \\
\hline Yalova & 277.4 & 95.9 & 161.5 & 50.0 & 88.9 & 56.7 & 219.1 & 84.0 & 746.9 & 143.5 \\
\hline Bursa & 267.0 & 87.1 & 181.8 & 57.1 & 68.1 & 37.8 & 190.3 & 71.1 & 707.3 & 138.3 \\
\hline Bilecik & 146.3 & 51.9 & 137.5 & 45.3 & 69.6 & 38.6 & 104.8 & 45.5 & 458.2 & 86.1 \\
\hline
\end{tabular}

Note. Std. Dev. $=$ Standard Deviation

Sezen (2018) implemented five homogeneity tests, namely Standard Normal Homogeneity Test (SNHT), Buishand Range Test, Pettitt Test, Von Neumann Ratio Test and lastly Kruskal-Wallis Test, to investigate the homogeneity of temperature and precipitation data. It was shown that $\mathrm{H}_{0}$ hypothesis [it assumes that the distribution of variables is identical and also they are independent (Wijngaard, 2003)] was rejected by all homogeneity tests in almost all stations (Edirne, Kırklareli, Kadıköy Rıh., Kocaeli, Yalova and Bilecik) except Bursa for the temperature data. Inhomogeneity in temperature data could be related with different factors such as spatially increasing or decreasing trends, urbanization and displacement of stations (Turkes et al, 2002; Sahin and Cigizoglu, 2010). On the other hand, $\mathrm{H}_{0}$ hypothesis was accepted by all homogeneity tests in all stations for the precipitation data. The trend analysis was not carried out in this study because it requires a more comprehensive research which exceeds the scope of this study.

\section{Correlation Analysis}

Correlation coefficients are calculated so as to reveal the statistical relation between the variables. High correlations could give a clue about the important relationship between the variables (Bayazit and Oguz, 2005). In this respect, Pearson correlation coefficients between atmospheric indices and climate variables were calculated described as follows: 


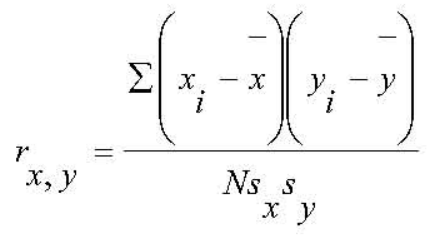

where $x_{i}$ stands for the annual or seasonal climate variable belongs to i.th year, $\bar{x}$ for the mean of climate variable, $y_{i}$ for annual or seasonal $\mathrm{NAO}$ or $\mathrm{AO}$ index pertains to i.th year, $\bar{y}$ for the mean of NAO or AO index, $\mathrm{N}$ for the data length, $s_{x}$ and $s_{y}$ for the standard deviations of climate variable and NAO or AO index, respectively (Sezen and Partal, 2017) The statistical importance of correlation coefficients was evaluated by using Student $t$ test at the significance level of $\alpha=0.10, \alpha=0.05$ and $\alpha=0.01$. The $t$ statistics is calculated as follows:

$$
t=\frac{r \sqrt{N-2}}{\sqrt{1-r^{2}}}
$$

where $r$ represents the correlation coefficient and $N$ denotes the data length. For example, correlation boundary value is $r \geq 0.34$ at $\alpha=0.01,0.26 \leq r<0.34$ and $\alpha=0.05$ and $0.22 \leq r<0.26$ $\alpha=0.10$ if the data length is $\mathrm{N}=56$ years.

\section{The Phases of Atmospheric Teleconnections}

In addition to correlation analysis, temperature and precipitation differences which derive from the negative and positive phases were calculated as seasonal and annual. This approach is significant in terms of observing the effects of positive and negative phases of NAO and AO. As for the physical phenomena of NAO, Turkes and Erlat (2009) stated that colder weather conditions are dominant over the greater part of Turkey under the effect of the positive phase of NAO. This weather pattern arises from the northeasterly circulation which is based on the low geopotential heights over Iceland low region and high geopotential heights over the Azores high region (Turkes and Erlat, 2009). While the southeasterly circulations lead to warmer weather conditions under the effect of negative phase of NAO throughout Turkey. As for the negative phase of AO circulations $500 \mathrm{hPa}$ height anomalies is high over Northern Africa, Middle East and low over North Atlantic-Europe region, it leads to warmer weather conditions due to warm air movement into Turkey (Turkes and Erlat, 2008). On the other hand, positive phase of AO causes the movement of cold air into Balkans and Turkey because of the northerly circulations (Turkes and Erlat, 2008). In this study, if NAO (AO) index has a value that is greater than or equal to 0.5 , it is accepted as NAO $(+)[\mathrm{AO}(+)]$. On the other hand, if NAO (AO) index has a value which is less than or equal to -0.5 , it is accepted as NAO (-) [AO (-)]. It is also shown in Table 4. Accordingly, the number of NAO (-) case is 15 for winter; 7 for spring; 15 for summer; 14 for the autumn season for the period of 1960-2015. In addition, the number of $\mathrm{NAO}(+)$ case is 17 for winter; 14 for spring; 8 for summer; 11 for the autumn season for the period of 1960-2015. As to the number of AO (-) for the period of $1960-2015$, it is 23 for winter; 13 for spring; 6 for summer; 12 for the autumn season. Furthermore, the number of $\mathrm{AO}(+)$ case is 14 for winter; 15 for spring; 3 for summer; 10 for the autumn season. 
Table 4

The Phases of Atmospheric Indices

\begin{tabular}{cc}
\hline Atmospheric Indice Range & Depiction of Atmospheric Indice Phase \\
\hline $\mathrm{NAO} \geq 0.5$ & $\mathrm{NAO}(+)$ \\
$\mathrm{NAO} \leq-0.5$ & $\mathrm{NAO}(-)$ \\
$\mathrm{AO} \geq 0.5$ & $\mathrm{AO}(+)$ \\
$\mathrm{AO} \leq-0.5$ & $\mathrm{AO}(-)$ \\
\hline
\end{tabular}

\section{Results}

\section{The Results of Correlation Analysis}

The correlations between the NAO and annual and seasonal temperature data are mostly negative. This points out that when NAO index tends to rise, the temperature is inclined to decrease. Besides, as it can be seen in Table 5, the most significant correlations between the $\mathrm{NAO}$ and temperature data were obtained in summer season in comparison to other seasons. The summer temperature data of all stations had a negative correlation with NAO index at the significance level of $\alpha=0.01$. In addition, in the winter season, the significant correlation coefficients were observed in eastern Marmara. This was compatible with the findings of Turkes and Erlat (2009). They also found significant correlations in the eastern and southern Marmara region during the winter season. Similarly, in the spring season the most remarkable correlations were acquired in eastern Marmara, whereas in autumn the season correlations coefficients were not significant at $\alpha=0.10, \alpha=0.05$ or $\alpha=0.01$. As annual, there were significant negative correlations, calculated only for Kocaeli and Bilecik stations at $\alpha=0.10$ and $\alpha=0.05$, respectively. As to the linkage between the NAO index and precipitation totals, it was seen that substantial negative correlations were obtained in the autumn season and as annual, especially. As indicated in Table 5, annual precipitation data of most stations were correlated with the NAO index at $\alpha=0.10, \alpha=0.05$ or $\alpha=0.01$.

Table 5

Correlations between NAO and Temperature, Precipitation Data

\begin{tabular}{|c|c|c|c|c|c|c|c|c|c|c|}
\hline \multirow{2}{*}{ Stations } & \multicolumn{5}{|c|}{ Temperature $\left({ }^{\circ} \mathrm{C}\right)$} & \multicolumn{5}{|c|}{ Precipitation $(\mathrm{mm})$} \\
\hline & Ann. & Wint. & Spr. & Sum. & Autumn & Ann. & Wint. & Spr. & Sum. & Autumn \\
\hline Edirne & $-0,16$ & 0,06 & $0,22^{*}$ & $-0,46^{* * * *}$ & $-0,14$ & $-0,33^{* *}$ & $-0,24^{*}$ & $-0,07$ & 0,08 & $-0,10$ \\
\hline Kırklareli & $-0,12$ & 0,06 & $-0,18$ & $-0,39^{* * * *}$ & $-0,12$ & $-0,32^{* *}$ & $-0,31^{* *}$ & $-0,12$ & 0,09 & $-0,15$ \\
\hline $\begin{array}{c}\text { Kadıköy } \\
\text { Rıh. }\end{array}$ & $-0,14$ & $-0,01$ & $-0,18$ & $-0,40^{* * * *}$ & $-0,10$ & $-0,22^{*}$ & $-0,15$ & $-0,12$ & 0,03 & $-0,15$ \\
\hline Kocaeli & $-0,24^{*}$ & $-0,23^{*}$ & $-0,30^{* *}$ & $-0,45^{* * * *}$ & $-0,12$ & $-0,14$ & $-0,14$ & $-0,22^{*}$ & 0,19 & $-0,35^{* * * *}$ \\
\hline Bilecik & $\overline{-}^{-}$ & $-0,24^{*}$ & $-0,28^{* *}$ & $-0,49^{* * *}$ & $-0,18$ & $-0,22^{*}$ & $-0,21$ & $-0,10$ & 0,03 & $-0,31^{* *}$ \\
\hline Bursa & $-0,18$ & $-0,31^{* *}$ & $-0,25^{*}$ & $-0,39^{* * * *}$ & $-0,14$ & $-0,35^{* * *}$ & $-0,20$ & $-0,11$ & 0,13 & $-0,29^{* *}$ \\
\hline Yalova & $-0,12$ & $-0,18$ & $-0,24^{*}$ & $-0,34^{* * *}$ & $-0,21$ & $-0,40^{* * * *}$ & $-0,31^{* *}$ & $-0,26^{* *}$ & 0,11 & $-0,33^{* *}$ \\
\hline
\end{tabular}

Note. ${ }^{*}$ stands for the significance level at $\alpha=0.10,{ }^{* *}$ stands for the significance level at $\alpha=0.05,{ }^{* * *}$ stands for the significance level at $\alpha=0.01$.

Furthermore, the significant correlations were calculated between the autumn precipitation data and NAO index. On the other hand, in other seasons the number of stations which have significant correlation with NAO is low, even in the summer season there were not observed any remarkable linkage between NAO and precipitation data. 
Table 6

Correlations between $A O$ and Temperature, Precipitation Data

\begin{tabular}{|c|c|c|c|c|c|c|c|c|c|c|}
\hline \multirow{2}{*}{ Stations } & \multicolumn{5}{|c|}{ Temperature $\left({ }^{\circ} \mathrm{C}\right)$} & \multicolumn{5}{|c|}{ Precipitation $(\mathrm{mm})$} \\
\hline & Ann. & Wint. & Spr. & Sum. & Autumn & Ann. & Wint. & Spr. & Sum. & Autumn \\
\hline Edirne & $-0,05$ & $-0,23^{*}$ & 0,14 & $-0,18$ & $-0,22^{*}$ & $-0,30^{* *}$ & $-0,50^{* * *}$ & $-0,14$ & $-0,07$ & $-0,21$ \\
\hline Kırklareli & $-0,03$ & $-0,26^{*}$ & 0,12 & $-0,12$ & $-0,21$ & $-0,32^{* *}$ & $-0,52^{* * *}$ & $-0,22$ & $-0,03$ & $-0,26^{*}$ \\
\hline $\begin{array}{l}\text { Kadıköy } \\
\text { Rih. }\end{array}$ & 0,01 & $-0,34^{* * *}$ & 0,05 & $-0,10$ & $-0,17$ & $-0,25^{*}$ & $-0,22^{*}$ & $-0,17$ & $-0,01$ & $-0,06$ \\
\hline Kocaeli & $-0,17$ & $-0,53^{* * *}$ & $-0,11$ & $-0,15$ & $-0,25^{*}$ & $-0,02$ & $-0,21$ & $-0,16$ & 0,02 & $-0,03$ \\
\hline Bilecik & $-0,19$ & $-0,51^{* * *}$ & $-0,05$ & $-0,11$ & $-0,32^{* *}$ & $-0,16$ & $-0,31^{* *}$ & $-0,06$ & $-0,09$ & $-0,16$ \\
\hline Bursa & $-0,17$ & $-0,60^{* * *}$ & $-0,04$ & $-0,09$ & $-0,23^{*}$ & $-0,19$ & $-0,34^{* * *}$ & $-0,06$ & 0,12 & $-0,20$ \\
\hline Yalova & $-0,05$ & $-0,51^{* * *}$ & $-0,05$ & $-0,05$ & $-0,30^{* *}$ & $-0,22^{*}$ & $-0,37^{* * *}$ & $-0,24^{*}$ & $0,24^{*}$ & $-0,08$ \\
\hline
\end{tabular}

Note. ${ }^{*}$ stands for the significance level at $\alpha=0.10,{ }^{* * *}$ stands for the significance level at $\alpha=0.05,{ }^{* * *}$ stands for the significance level at $\alpha=0.01$.

As it can be realized from Table 6, in the winter season correlations between the $\mathrm{AO}$ and temperature data are high, particularly in the eastern part of Marmara region. Furthermore, considerable correlations were also observed between the autumn temperature and $\mathrm{AO}$ at $\alpha=0.10$ or $\alpha=0.05$.

On the other hand, in other seasons the relationship between the AO and temperature data was weak statistically. Similarly, there were not any strong correlations between annual temperature and $\mathrm{AO}$. In the greater part of the region, the precipitation had strong negative correlations with the $\mathrm{AO}$. However, the correlations between $\mathrm{AO}$ and precipitation data were not statistically strong in other seasons. As for the connection between AO and annual precipitation, there were substantial correlations in northwestern Marmara.

\section{The Temperature and Precipitation Differences Based on Phases of Atmospheric Indices}

The temperature differences which are based on the NAO (-) and NAO (+) are shown in Table 7. According to Table 7, the temperature values under the impact of NAO (-) are higher than the temperature values under the effect of NAO $(+)$, generally. Moreover, the most significant temperature differences were obtained in the summer and spring seasons as compared with the other seasons. Annual temperature differences also were between $0.5{ }^{\circ} \mathrm{C}$ and $1^{\circ} \mathrm{C}$ as seen in Table 7 . 
Table 7

Temperature Differences Based on NAO (-) and NAO (+)

\begin{tabular}{|c|c|c|c|c|c|c|c|c|c|c|c|c|c|c|c|}
\hline \multirow{3}{*}{ Stations } & \multicolumn{15}{|c|}{ Temperature $\left({ }^{\circ} \mathrm{C}\right)$} \\
\hline & \multicolumn{3}{|c|}{ Annual } & \multicolumn{3}{|c|}{ Winter } & \multicolumn{3}{|c|}{ Spring } & \multicolumn{3}{|c|}{ Summer } & \multicolumn{3}{|c|}{ Autumn } \\
\hline & $\frac{I}{\frac{I}{1}}$ & $\frac{ \pm}{\stackrel{ \pm}{Z}}$ & 范 & $\frac{I}{\frac{I}{0}}$ & $\frac{\mp}{\frac{ \pm}{2}}$ & 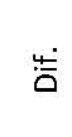 & $\frac{I}{0}$ & $\frac{\mp}{\frac{ \pm}{2}}$ & 范 & $\frac{I}{\frac{I}{0}}$ & $\frac{\mp}{\frac{ \pm}{2}}$ & 岮 & $\frac{I}{\frac{I}{1}}$ & $\frac{ \pm}{\frac{ \pm}{2}}$ & 猋 \\
\hline Edirne & 14.3 & 13.8 & 0.5 & 3.9 & 4.0 & $\begin{array}{l}- \\
0.1\end{array}$ & 14 & 13 & 1 & 24.7 & 23.6 & 1.1 & 14.4 & 14.1 & 0.3 \\
\hline Kirklareli & 13,8 & 13.3 & 0.5 & 3.9 & 4.1 & $\begin{array}{l}- \\
0.2\end{array}$ & 13.1 & 12.2 & 0.9 & 23.5 & 22.7 & 0.8 & 14 & 13.7 & 0.3 \\
\hline $\begin{array}{l}\text { Kadiköy } \\
\text { Rih. }\end{array}$ & 15.2 & 14.4 & 0.8 & 6.9 & 6.9 & 0 & 13.3 & 12.4 & 0.9 & 23.9 & 22.9 & 1 & 15.9 & 15.7 & 0.2 \\
\hline Kocaeli & 15.5 & 14.6 & 0.9 & 7.6 & 7 & 0.6 & 14.1 & 12.9 & 1.2 & 23.7 & 22.7 & 1 & 16.1 & 15.8 & 0.3 \\
\hline Bilecik & 13.3 & 12.3 & 1 & 4.1 & 3.5 & 0.6 & 12.6 & 11.4 & 1.2 & 22.2 & 20.9 & 1.3 & 13.9 & 13.3 & 0.6 \\
\hline Bursa & 15.1 & 14.4 & 0.7 & 6.9 & 6.2 & 0.7 & 14.0 & 13.0 & 1 & 24.3 & 23.3 & 1 & 15.5 & 15.1 & 0.4 \\
\hline Yalova & 15.3 & 14.6 & 0.7 & 7.6 & 7.3 & 0.3 & 13.5 & 12.6 & 0.9 & 23.5 & 22.6 & 0.9 & 16 & 15.6 & 0.4 \\
\hline
\end{tabular}

When the relationship between the precipitation regime and $\mathrm{NAO}(-), \mathrm{NAO}(+)$ was taken into consideration, the annual precipitation differences were significant, in particular. Besides, according Table 8 there are also significant precipitation differences in the winter and autumn seasons, while in the spring and summer seasons precipitation differences are less relatively.

Table 8

Precipitation Differences Based on NAO (-) and NAO (+)

\begin{tabular}{|c|c|c|c|c|c|c|c|c|c|c|c|c|c|c|c|}
\hline \multirow{3}{*}{ Stations } & \multicolumn{15}{|c|}{ Precipitation (mm) } \\
\hline & \multicolumn{3}{|c|}{ Annual } & \multicolumn{3}{|c|}{ Winter } & \multicolumn{3}{|c|}{ Spring } & \multicolumn{3}{|c|}{ Summer } & \multicolumn{3}{|c|}{ Autumn } \\
\hline & $\frac{I}{0}$ & $\frac{ \pm}{\stackrel{ \pm}{0}}$ & 岁 & $\frac{I}{\frac{1}{0}}$ & $\frac{\mp}{\stackrel{ \pm}{0}}$ & 范 & $\frac{I}{\frac{1}{0}}$ & $\frac{ \pm}{ \pm}$ & 嵅 & $\frac{I}{0}$ & $\frac{ \pm}{0}$ & 范 & $\frac{T}{0}$ & $\frac{\mp}{\stackrel{ \pm}{0}}$ & 范 \\
\hline Edirne & 764 & 508 & 256 & 216 & 178 & 38 & 124 & 131 & -7 & 92 & 102 & -10 & 172 & 146 & 26 \\
\hline Kırklareli & 667 & 445 & 222 & 221 & 167 & 54 & 121 & 112 & 9 & 91 & 99 & -8 & 176 & 133 & 43 \\
\hline $\begin{array}{c}\text { Kadıköy } \\
\text { Rıh. }\end{array}$ & 759 & 620 & 139 & 282 & 246 & 36 & 131 & 119 & 12 & 73 & 60 & 13 & 208 & 167 & 41 \\
\hline Kocaeli & 958 & 794 & 164 & 282 & 271 & 11 & 187 & 152 & 35 & 123 & 147 & -24 & 284 & 203 & 81 \\
\hline Bilecik & 605 & 478 & 127 & 156 & 134 & 22 & 146 & 126 & 20 & 70 & 75 & -5 & 125 & 87 & 38 \\
\hline Bursa & 1015 & 628 & 387 & 289 & 255 & 34 & 173 & 162 & 11 & 65 & 74 & -9 & 225 & 172 & 53 \\
\hline Yalova & 1081 & 688 & 393 & 311 & 256 & 55 & 160 & 135 & 25 & 84 & 91 & -7 & 272 & 192 & 80 \\
\hline
\end{tabular}

As inferred from Table 9, in comparison with the NAO, the most remarkable temperature differences between $\mathrm{AO}(-)$ and $\mathrm{AO}(+)$ were calculated in winter especially in eastern Marmara. In similar to the winter season, in the autumn season there are also remarkable differences in eastern Marmara. On the other hand, the temperature differences are not quite high in the spring season and as annual. In the summer season, temperature values of some stations seem to be influenced by $\mathrm{AO}(-)$ and $\mathrm{AO}(+)$. 
Table 9

Temperature Differences based on $A O(-)$ and $A O(+)$

\begin{tabular}{|c|c|c|c|c|c|c|c|c|c|c|c|c|c|c|c|}
\hline \multirow{3}{*}{ Stations } & \multicolumn{15}{|c|}{ Temperature $\left({ }^{\circ} \mathrm{C}\right)$} \\
\hline & \multicolumn{3}{|c|}{ Annual } & \multicolumn{3}{|c|}{ Winter } & \multicolumn{3}{|c|}{ Spring } & \multicolumn{3}{|c|}{ Summer } & \multicolumn{3}{|c|}{ Autumn } \\
\hline & $\stackrel{1}{1}$ & 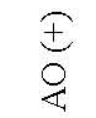 & 㻙 & $\stackrel{1}{\stackrel{1}{4}}$ & $\underset{\bigotimes}{\stackrel{\Xi}{\rightleftarrows}}$ & 崩 & 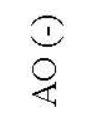 & 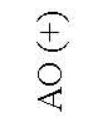 & 崩 & 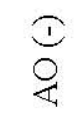 & 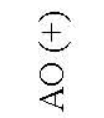 & 㟔 & 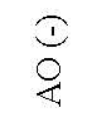 & 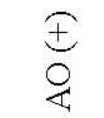 & 崩 \\
\hline Edirne & 14.0 & 14.1 & -0.1 & 4.0 & 3.5 & 0.5 & 13.0 & 13.2 & -0.2 & 24.0 & 23.0 & 1.0 & 14.8 & 14.1 & 0.7 \\
\hline Kurklareli & 13.4 & 13.7 & -0.3 & 4.1 & 3.6 & 0.5 & 12.1 & 12.3 & -0.2 & 23.1 & 22.4 & 0.7 & 14.4 & 13.8 & 0.6 \\
\hline $\begin{array}{c}\text { Kadıköy } \\
\text { Rih. }\end{array}$ & 14.6 & 15.0 & -0.4 & 7.0 & 6.4 & 0.6 & 12.3 & 12.5 & -0.2 & 23.1 & 22.7 & 0.4 & 16.3 & 15.8 & 0.5 \\
\hline Kocaeli & 15.2 & 15.1 & 0.1 & 7.6 & 6.4 & 1.2 & 13.4 & 13 & 0.4 & 23.3 & 22.6 & 0.7 & 16.5 & 15.8 & 0.7 \\
\hline Bilecik & 12.8 & 12.8 & 0 & 4.2 & 2.6 & 1.6 & 11.6 & 11.5 & 0.1 & 21.4 & 20.9 & 0.5 & 14.3 & 13.3 & 1.0 \\
\hline Bursa & 14.8 & 14.9 & -0.1 & 7.0 & 5.3 & 1.7 & 13.1 & 13 & 0.1 & 23.7 & 23.4 & 0.3 & 15.8 & 15.2 & 0.6 \\
\hline Yalova & 14.8 & 15 & -0.2 & 7.7 & 6.7 & 1.0 & 12.6 & 12.6 & 0 & 22.8 & 22.6 & 0.2 & 16.3 & 15.6 & 0.7 \\
\hline
\end{tabular}

In Table 10, precipitation differences that are depending upon the $\mathrm{AO}(-)$ and $\mathrm{AO}(+)$ were demonstrated. In this regard, significant annual precipitation differences were observed in northwestern Marmara. It can be noticed that the annual precipitation under the effect of $\mathrm{AO}$ $(-)$ is less than the annual precipitation values under the impact of $\mathrm{AO}(+)$ particularly in eastern Marmara. As for the winter season, there were remarkable precipitation differences between the $\mathrm{AO}(-)$ and $\mathrm{AO}(+)$ in the greater part of the region. The other point was that the quantity of summer precipitation under the influence of AO (-) was less than the amount of the precipitation under the effect of $\mathrm{AO}(+)$. In other seasons, the precipitation values which were based on $\mathrm{AO}(-)$ and $\mathrm{AO}(-)$ were close to each other in the majority of region.

Table 10

Precipitation Differences Based on $A O(-)$ and $A O(+)$

\begin{tabular}{|c|c|c|c|c|c|c|c|c|c|c|c|c|c|c|c|}
\hline \multirow{3}{*}{ Stations } & \multicolumn{15}{|c|}{ Precipitation $(\mathrm{mm})$} \\
\hline & \multicolumn{3}{|c|}{ Annual } & \multicolumn{3}{|c|}{ Winter } & \multicolumn{3}{|c|}{ Spring } & \multicolumn{3}{|c|}{ Summer } & \multicolumn{3}{|c|}{ Autumn } \\
\hline & 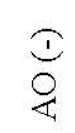 & 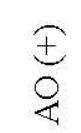 & 崩 & $\stackrel{1}{1}$ & 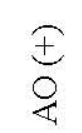 & 㟒 & 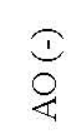 & 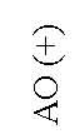 & 岗 & $\stackrel{1}{0}$ & $\begin{array}{l}\text { } \\
\stackrel{2}{4}\end{array}$ & 㟒 & 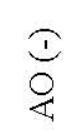 & 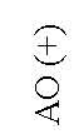 & 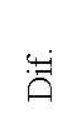 \\
\hline Edirne & 638 & 579 & 59 & 219 & 146 & 73 & 147 & 146 & 1 & 116 & 122 & -6 & 176 & 163 & 13 \\
\hline Kırklareli & 638 & 503 & 135 & 217 & 139 & 78 & 139 & 121 & 18 & 94 & 114 & -20 & 176 & 144 & 32 \\
\hline $\begin{array}{c}\text { Kadıköy } \\
\text { Rih. }\end{array}$ & 678 & 590 & 88 & 274 & 219 & 55 & 137 & 123 & 14 & 65 & 63 & 2 & 184 & 168 & 16 \\
\hline Kocaeli & 758 & 797 & -39 & 286 & 258 & 28 & 177 & 152 & 25 & 113 & 151 & -38 & 218 & 239 & -21 \\
\hline Bilecik & 476 & 489 & -13 & 163 & 136 & 27 & 134 & 123 & 11 & 62 & 88 & -26 & 113 & 101 & 12 \\
\hline Bursa & 725 & 761 & -36 & 289 & 239 & 50 & 182 & 170 & 12 & 55 & 92 & -37 & 221 & 189 & 32 \\
\hline Yalova & 763 & 738 & 25 & 293 & 233 & 60 & 173 & 138 & 35 & 57 & 126 & -69 & 230 & 206 & 24 \\
\hline
\end{tabular}




\section{Conclusion and Discussion}

In this study, it is aimed to determine the relationship between temperature, precipitation and $\mathrm{NAO}, \mathrm{AO}$ in Eastern and Northern Marmara in Turkey.

In this context, the most significant linkage between the NAO and temperature was observed in the summer season. On the other hand, for the relation between AO and temperature regime, the remarkable results were obtained in the winter and partly autumn seasons. This shows that if the $\mathrm{AO}$ index has an increasing trend, the winter temperature values have a decreasing inclination. Especially, the results which were obtained for AO and temperature regime are consistent with the results of Turkes and Erlat (2008). They also found that $\mathrm{AO}$ index is negatively correlated with winter temperature. According to Turkes and Erlat (2008), this could be related with the influences by $\mathrm{AO}(-)$ and $\mathrm{AO}(+)$ which lead to westerly, southwesterly flows and northerly flows over Turkey, respectively.

Correlations between the NAO and summer temperature are significant compared with the AO. Accordingly, further analysis should be carried out whether or not NAO really affects the summer seasonal characteristics. Turkes and Erlat (2009) find the negative correlations between NAO and temperature data in Eastern Marmara during the winter season. In this study, significant negative relationship between NAO and winter temperature were also obtained especially in Eastern Marmara. Accordingly, findings of this study comply with the findings of study of Turkes and Erlat (2009). Correlation analysis and precipitation differences indicate that NAO has a relationship with the annual and autumn precipitation particularly in Eastern Marmara. During the winter season, significant correlations between NAO and precipitation were not observed in majority of Eastern Marmara. This is compatible with the findings of study which was carried out by Karabork et al (2005). They do not also find significant correlations between winter precipitation and NAO particularly in northeastern Marmara. On the other hand, winter precipitation and $\mathrm{AO}$ has a strong relationship in Marmara region when correlations and precipitation differences are taken into account. In addition, significant annual precipitation differences were also acquired especially in northwestern Marmara.

This study demonstrates that not only NAO but also AO could have a relationship with the temperature and precipitation regime of Eastern and Northern Marmara. When considered from this point of view, the role of atmospheric teleconnections could be substantial on the hydrological cycle and water resources management. In other words, atmospheric teleconnection can lead to decrease or increase in precipitation, temperature or other hydrometeorological variables. Thus, the relationship between atmospheric teleconnections and hydrometeorological variables should be taken into account for the planning of water structures such as dams or weirs and taking measures against extreme events like flood or drought. Further comprehensive studies need be carried out so as to determine to what extent atmospheric indices could affect the hydrometeorological variables and thereby water cycle in the nature.

\section{Acknowledgment}

The results of this study are part of the Master's thesis of Cenk Sezen, namely "Effects of global atmospheric indexes on temperature and precipitation data in Turkey". 


\section{References}

Bayazıt, M., \& Oguz, Y. B. E. (2005).Mühendislik için istatistik. İstanbul:Birsen Yayınevi.

Brönnimann, S. (2007). Impact of El Niño-Southern oscillation on European climate. Reviews of Geophysics, 45, RG3003.

Burt, T., \& Howden, N. (2013). North Atlantic oscillation amplifies orographic precipitation and river flow in upland Britain. Water Resources Research, 49(6), 3504-3515.

Chowdhury, R., \& Beecham, S. (2010). Australian rainfall trends and their relation to the Southern oscillation index. Hydrological Processes, 24(4), 504-514.

Climate Prediction Center, National Weather Service, NOAA, North Atlantic Oscillation (NAO) Index (2018). Retrieved January 2, 2018, from http://www.cpc.ncep.noaa.gov/products/precip/CWlink/pna/norm.nao.monthly.b5001.current.ascii.table

Climate Prediction Center, National Weather Service, NOAA, Arctic Oscillation (AO) Index (2018). Retrieved January 2, 2018, from http://www.cpc.ncep.noaa.gov/products/precip/CWlink/daily_ao_index/ao.shtml

Cullen, H. M., Kaplan, A. \&Arkin, P. A. 2002. Impact of the North Atlantic Oscillation on Middle Eastern climate and streamflow. Climatic Change, 55(3), 315-338.

Givati, A., \& Rosenfeld, D. (2013). The Arctic oscillation, climate change and the effects on precipitation in Israel. Atmospheric Research, 132, 114-124.

Kadioglu, M., Tulunay, Y. \& Borhan, Y. (1999). Variability of Turkish precipitation compared to El Nino events. Geophysical Research Letters, 26(11), 1597-1600.

Kahya, E., \& Karabork, M. C. (2001). The analysis of El Nino and La Nina signals in streamflows of Turkey. Intemational Joumal of Climatology, 21(10), 1231-1250.

Karabork, M. C., Kahya, E. \& Karaca, M. (2005). The influences of the Southern and North Atlantic oscillations on climatic surface variables in Turkey. Hydrological Processes, 19(6), 1185-1211.

Karabork, M. C., \& Kahya, E. (2009). The links between the categorised Southern Oscillation indicators and climate and hydrologic variables in Turkey. Hydrological Processes, 23(13), 1927-1936.

Kucuk, M., Kahya, E., Cengiz, T. M. \& Karaca, M. (2009). North Atlantic oscillation influences on Turkish lake levels. Hydrological Processes, 23(6), 893-906.

Rodo, X., Baert, E., \& Comin F. (1997). Variations in seasonal rainfall in Southern Europe during the present century: relationships with the North Atlantic oscillation and the El Niño-Southern oscillation. Climate Dynamics, 13(4), 275-284.

Sahin, S., \& Cigizoglu, H. K. (2010). Homogeneity analysis of Turkish meteorological data set. Hydrological Processes, 24(8), 981-992.

Sezen, C., \& Partal, T. (2017). The relation of North Atlantic oscillation (NAO) and North Sea Caspian pattern (NCP) with climate variables in Mediterranean region of Turkey. The Eurasia Proceedings of Science, Technology, Engineering \& Mathematics, 1, 366-371.

Sezen, C. (2018). Effects of global atmospheric indexes on temperature and precipitation data in Turkey. (Master's thesis).

Thompson, D. W., \& Wallace, J. M. (1998). The Arctic oscillation signature in the wintertime geopotential height and temperature fields. Geophysical Research Letters, 25(9), 1297-1300. 
Tremblay, L., Larocque, M., Anctil, F. \& Rivard, C. (2011). Teleconnections and interannual variability in Canadian groundwater levels. Joumal of Hydrology, 410(3), 178-188.

Turkes, M., Sumer, U. M. \& Demir, G. I. (2002). Reevaluation of trends and changes in mean, maximum and minimum temperatures of Turkey for the period 1929-1999. International Joumal of Climatology, 22(8), 947-977.

Turkes, M., \& Erlat, E. (2003). Precipitation changes and variability in Turkey linked to the North Atlantic Oscillation during the period 1930-2000. International Joumal of Climatology, 23(14), 1771-1796.

Turkes, M. \& Erlat, E. (2008). Influence of the arctic oscillation on the variability of winter mean temperatures in Turkey. Theoretical and Applied Climatology, 92(1), 75-85.

Turkes, M. \& Erlat, E. (2009). Winter mean temperature variability in Turkey associated with the North Atlantic oscillation. Meteorology and Atmospheric Physics, 105(3-4), 211-225.

Wang, D., Wang, C., Yang, X. \& Lu, J. (2005). Winter Northern hemisphere surface air temperature variability associated with the Arctic oscillation and North Atlantic oscillation. Geophysical Research Letters, 32(16).

Wang, S., Zhang, M., Sun, M., Wang, B. \& Li, X. (2013). Changes in precipitation extremes in alpine areas of theChinese Tianshanmountains. Central Asia, 1961-2011, Quaternary International, (311), 97-107.

Wijngaard, J., Klein, T. A. \& Können, G. (2003). Homogeneity of 20th century European daily temperature and precipitation series. International Journal of Climatology, 23(6), 679-692. 


\section{Extended Turkish Abstract (Genişletilmiş Türkçe Özet)}

\section{Arktik \& Kuzey Atlantik Salınımlarının Doğu ve Kuzey Marmara'nın Sıcaklık ve Yağış Verileri Üzerindeki Etkileri}

Atmosferik olayların, hidrolojik döngü ve su kaynaklarının planlanması üzerindeki etkilerinin belirlenmesi büyük önem arz etmektedir. Atmosferik salınımlar ile hidrometeorolojik değişkenlerin arasındaki ilişkiyi belirlemeye yönelik gerçekleştirilen çalışmalar da bu alanda yapılanlar arasında yer almaktadır. Buna göre, Kuzey Atlantik Salınımı (NAO) ve Arktik Salınım (AO) gibi küresel atmosferik indislerin yağış, sıcaklık ve akış gibi hidrolojik değişkenler üzerindeki etkilerinin ortaya çıkarılması su kaynaklarının yönetimi açısından önemlidir. $\mathrm{Bu}$ amaçla çalışmamızda $\mathrm{NAO}, \mathrm{AO}$ atmosferik indisleri ile Türkiye'nin kuzeybatısında yer alan Marmara Bölgesi' nin doğusu ve kuzeyinde sıcaklık ve yağış rejimi arasında herhangi bir etkileşim olup olmadığı araştırılmıştır.

$\mathrm{Bu}$ çalışmada, Marmara Bölgesi'nde yer alan 7 istasyona (Edirne, Kırklareli, Kadıköy Rıh, Kocaeli, Yalova, Bursa ve Bilecik) ait sıcaklık ve yağı̧̧ verileri kullanılmıştır. Söz konusu veriler genel itibariyle 19602015 dönemini kapsamaktadır. Atmosferik indisler (NAO, AO) ve hidrometeorolojik parametreler arasındaki ilişki, kış (Aralık, Ocak, Şubat), ilkbahar (Mart, Nisan, Mayıs), yaz (Haziran, Temmuz, Ağustos) ve sonbahar (Eylül, Ekim, Kasım) mevsimleri için ve yıllık olarak araştırılmıştır. Buna göre, ilk olarak AO, NAO indisleri ile sıcaklık ve yağış verileri arasındaki korelasyon katsayıları hesaplanmıştır. Korelasyon katsayılarının istatistiksel olarak değerlendirilmesi ise Student $t$ testine göre gerçekleştirilmiştir. Daha sonra, AO ve NAO indislerinin negatif $[\mathrm{AO}(-)$, NAO (-)] ve pozitif $[\mathrm{AO}(+)$ ve $\mathrm{NAO}(+)]$ fazları nedeniyle oluşan sıcaklık ve yağış farkları hesaplanmıştır.

NAO ile sicaklık verisi arasında genel olarak negatif korelasyonlar elde edilmiştir. Bu durum, NAO indeksinin değerinin düşmesi ile birlikte sıcaklık değerinin arttığına işaret etmektedir. Bununla birlikte, NAO ile sıcaklık verisi arasında en önemli korelasyonlar özellikle yaz mevsiminde elde edilmiștir. Kış ve ilkbahar mevsimlerinde ise bölgenin doğusunda önemli negatif korelasyonlar tespit edilmiştir. NAO ile yağış verisi arasında ise birçok istasyonda yılllk olarak önemli korelasyonlar görülmüştür. Bunun dışında, özellikle sonbahar mevsiminde bölgenin doğusunda da önemli negatif korelasyonlar görülmüştür. AO ile kış sıcaklık verisi arasında ise bilhassa Marmara Bölgesi'nin doğusunda yüksek negatif korelasyonlar gözlenmiştir. Ayrıca, sonbahar mevsiminde de $\mathrm{AO}$ ve sıcaklık verisi arasında istatistiksel olarak önemli bir iliş̧ki tespit edilirken, diğer mevsimlerde ise $\mathrm{AO}$ ile sıcaklık arasındaki ilişkinin daha az olduğu görülmüş̧ür. AO ile yağış arasında da kış mevsiminde ve kısmen yıllık olarak önemli bir ilişki olduğu elde edilmiştir.

Korelasyon analizinin tamamlanmasının ardından, yıllık ve mevsimsel sıcaklık değerlerinin, NAO ve AO indekslerinin negatif ve pozitif fazlarından etkilenip etkilenmediği araştıılmıştır. $\mathrm{NAO}(-), \mathrm{AO}(-), \mathrm{NAO}(+), \mathrm{AO}$ $(+)$ etkisi altında ortalama sıcaklık ve toplam yağış değerleri hesaplanmıştır. Buna bağlı olarak, mevsimsel ve yıllık sıcaklık, yağıș farkları elde edilmiştir. İlk olarak NAO indeksinin negatif ve pozitif fazlarının etkileri analiz edildiğinde, genel itibariyle $\mathrm{NAO}(-)$ etkisi altındaki sıcaklık değerlerinin, $\mathrm{NAO}(+)$ etkisi altındaki sıcaklık değerlerinden daha fazla olduğu görülmüştür. Bununla birlikte, sıcaklık farklarının bilhassa ilkbahar $\left(0.9-1.2^{\circ} \mathrm{C}\right)$ ve yaz $\left(0.8-1.3^{\circ} \mathrm{C}\right)$ mevsimlerinde diğer mevsimlere nazaran daha fazla olduğu tespit edilmiştir. NAO indeksinin negatif ve pozitif fazları ile yağıs rejimi arasındaki ilişki irdelendiğinde ise, yaz mevsimi haricinde diğer mevsimlerde ve yıllık olarak NAO (-) etkisi altındaki yağı̧ miktarının, $\mathrm{NAO}(+)$ etkisi altındaki yağış miktarından genellikle daha fazla olduğu görülmüştür. Buna göre, özellikle sonbahar ve kış mevsimlerinde diğer mevsimlere oranla yağış farklarının daha fazla olduğu tespit edilmiştir. Ayrıca yıllık olarak da önemli yağış farkları hesaplanmıştır. $\mathrm{AO}(-)$ ve $\mathrm{AO}(+)$ etkisi nedeniyle oluşan sıcaklık farkları özellikle kış mevsiminde $\left(0.5-1.7^{\circ} \mathrm{C}\right)$ daha fazla olup, sonbahar mevsiminde $\left(0.5-1{ }^{\circ} \mathrm{C}\right)$ ve yaz mevsiminde $\left(0.2-1{ }^{\circ} \mathrm{C}\right)$ de sicaklık farklar1 elde edilmiștir. İlkbahar mevsiminde ve yıllık olarak ise önemli sıcaklık farkları gözlenmemiștir. AO indeksinin negatif ve pozitif fazı etkisiyle oluşan yağış farkları incelendiğinde ise, $\mathrm{AO}(-)$ etkisi altında yağış miktarının kış, ilkbahar ve sonbahar mevsimlerinde $\mathrm{AO}(+)$ etkisi altındaki yağıș değerlerinden daha fazla olduğu görülmüștür. NAO indeksine benzer şekilde, yaz mevsiminde $\mathrm{AO}(+)$ etkisi altında yağış miktarının $\mathrm{AO}(-)$ etkisi altındaki yağış miktarından fazla olduğu tespit edilirken, aynı şekilde yılllk olarak özellikle Marmara Bölgesi’nin doğusunda AO $(+)$ etkisi altındaki yağış miktarının, $\mathrm{AO}(-)$ etkisi altındaki yağış miktarından daha fazla olduğu görülmüştür. 
$\mathrm{Bu}$ çalışmada, $\mathrm{NAO}$ ve $\mathrm{AO}$ indeksleri ile Türkiye'nin Marmara Bölgesi'nin doğusunda ve kuzeyinde sıcaklık ve yağış verileri arasında mevsimsel ve yıllık olarak bir ilişki olup olmadığı gösterilmeye çalışılmıştır. Buna göre, sıcaklık verisinin NAO indeksi ile etkileşiminin özellikle yaz mevsiminde, AO indeksi ile ise kış mevsiminde kuvvetli olduğu ifade edilebilir. Bununla birlikte, sıcaklık verisi ile atmosferik indisler arasinda gerçekleştirilen korelasyon analizi ve sıcaklık fark analizi sonuçlarının genel olarak birbirleriyle uyumlu olduğu söylenebilir. Yağış verisinin NAO indeksi ile ilişkisinin kış, sonbahar mevsimlerinde ve yıllık olarak, AO indeksi ile ilişkisinin ise bilhassa kış mevsiminde ve yıllık olarak güçlü olduğu gözlenmiştir. Fakat yağış verisi ile atmosferik indisler arasında gerçekleştirilen analizler göz önüne alındığında, aralarındaki ilişkinin sıcaklık verisine göre daha karmaşık olduğu ifade edilebilir. Elde edilen sonuçlar, atmosferik indisler ile hidrometeorolojik değişkenler arasında önemli bir ilişki olabileceğini göstermekte, bu durumun hidrolojik döngü, su kaynaklar1 planlaması ve yönetimi açısından önem arz ettiğini ortaya koymaktadır. Daha sonraki çalışmalarda atmosferik salınımlar ile hidrometeorolojik değişkenler arasında herhangi bir ilişki olup olmadığını belirlemek amacıyla farklı analiz yöntemleri araştırılacaktır. 